\title{
The impact of human resource management activities on job satisfaction
}

\section{Утицај активности менаџмента људских ресурса на задовољство послом}

\author{
Dragana Došenović* \\ University of Banja Luka, Faculty of Economics, Banja Luka, Bosnia and Herzegovina, \\ dragana.dosenovic@ef.unibl.org \\ Branka Zolak Poljašević \\ University of Banja Luka, Faculty of Economics, Banja Luka, Bosnia and Herzegovina, \\ branka.zolak-poljasevic@ef.unibl.org
}

\begin{abstract}
Although there are numerous and various factors that can affect job satisfaction, human resource management has been identified as one of the most important causes of job satisfaction. For this reason, this paper analyses the impact of human resource management and its activities on job satisfaction in various organizations in the Republic of Srpska, with the main goal to investigate and determine the existence and nature of the relationship between human resource management activities, as an independent variable, and job satisfaction, as a dependent variable. In order to analyse the observed relationship, an empirical research was conducted on a sample of 738 employees from 283 organizations from the Republic of Srpska. The research was conducted using a specially created survey questionnaire, and the reliability of the created instrument was calculated using the Cronbach's alpha coefficient. Based on the results of the research, which were obtained by correlation analysis, the basic hypothesis was confirmed, which proved that human resource management activities have a statistically significant effect on job satisfaction. Also, all additional hypotheses, claiming that individual human resources management activities (recruitment and selection, training, development and rewarding) have a positive effect on job satisfaction, were confirmed.
\end{abstract}

Keywords: human resource management, staffing, human resource development, rewarding, job satisfaction JEL classification: J24, J28, M12, M54

Сажетак: Иако постоји велики број фактора који могу утицати на задовољство послом, менаџмент људских ресурса је идентификован као један од најважнијих узрока задовољства послом. Управо из тог разлога у овом раду се анализира утицај менаџмента људских ресурса и његових активности на задовољство послом у различитим организацијама из Републике Српске, са основним циљем да се истражи и утврди постојање и природа везе између активности менаџмента људских ресурса, као независне варијабле, и задовољства послом, као зависне варијабле. Да би се анализирала посматрана веза спроведено је емпиријско истраживање на узорку од 738 радника из 283 организације из Републике Српске. Истраживање је спроведено помоћу посебно креираног анкетног упитника, а поузданост креираног инструмента израчуната је помоћу Кронбаховог коефицијента алфа. На основу резултата истраживања, који су добијени помоћу корелационе анализе, потврђена је основна хипотеза, на основу чега је доказано да активности менаџмента људских ресурса утичу на задовољство послом. Такође, потврђене су и све помоћне хипотезе којима се тврди да појединачне активности менаџмента људских ресурса (регрутовање и селекција, обука, развој и награђивање) позитивно утичу на задовољство послом.

* Corresponding author 
Кључне речи: менаџмент људских ресурса, запошљавање, развој људских ресурса, награђивање, задовољство послом

JEЛ класификација: J24, J28, M12, M54

\section{Introduction}

As employees or human resources are an integral part of any organization, their role in achieving the organization's goals has often been the subject of various discussions (Barney, 1991; Huselid, 1995). Although the opinions of the authors are different, many authors treat human resources as the most valuable type of resource (Barney \& Wright, 1998) and a very important source of competitive advantage (Wang \& Barney, 2006; Vemić-Đurković et al., 2020). It is considered that quality human resources having adequate knowledge, skills and abilities are the key to successful business. However, in addition to the competencies of employees, motivation and job satisfaction play a big role in exploiting their potentials, with which employees can be directed towards achieving the set goals (Aleksić-Glišović et al., 2019). Thus, the behaviour of employees in the desired way is usually provided by a high level of their job satisfaction. However, in order to achieve a high level of satisfaction, it is necessary for the organization to discover the causes or factors that affect the satisfaction of its employees. Although numerous factors of job satisfaction have been identified in the existing literature (Pan, 2015), one of the most important is human resource management (hereinafter HRM), which refers to a set of activities that are used for managing human resources in organizations.

The relationship between HRM and job satisfaction is often discussed in theory in the field of organization and management (Purcell et al., 2003; Paauwe, 2004; Currall et al., 2005; Heneman, 2007; Tyson, 2015; Mathis et al., 2015; Gómez-Mejía et al., 2016; Armstrong, 2017; Torrington et al., 2017; Noe et al., 2018). Although theoretically recognized, the relationship between the observed variables has not yet been fully explored. Although some empirical research linking HRM to job satisfaction has been conducted, the analysis has shown that previous research has a number of shortcomings. Certainly the biggest shortcoming is the comprehensiveness of the research, since they are focused only on the analysis of the impact of certain HRM activities on job satisfaction, and therefore do not offer a complete picture of the researched phenomenon. Thus, existing research has a partial approach to analysis, given that only a small number of characteristics of the analysed HRM activities are included in most such research, where certain important characteristics are often neglected. Also, the analysis showed that there are no studies that adequately shed light on the relationship between the observed variables in the context of developing countries and countries in transition.

For these reasons, the subject of research in this paper is the impact of HRM activities on job satisfaction in various organizations operating in the Republic of Srpska, while the main goal of the paper is to investigate and determine the existence and nature of the relationship between the observed variables. In order to analyse the observed impact and prove the set hypotheses, an empirical research was conducted on a sample of 738 
workers employed in 283 organizations from the Republic of Srpska. A specially created survey questionnaire was used in the research.

The paper consists of several parts. In the first part of the paper, after the introduction, the theoretical background of the analysis is presented. The next part of the paper includes the research methodology in which the research methods and techniques are presented, as well as the sample on which the research was conducted. The results of the research and discussion are presented in the third part. Finally, there is a conclusion within which the basic limitations of the research and the recommendations for future research are stated.

\section{Theoretical background}

Job satisfaction. The concept of job satisfaction, which is most often defined as a pleasurable or positive emotional state resulting from the appraisal of one's job or job experiences (Locke, 1969, 1976), is one of the most important and most researched attitudes that employees have about their work (Davis, 2004; George \& Jones, 2012; McPhail et al., 2015). The relevance of the observed concept is the result of the belief that changes in the level of job satisfaction have numerous positive, but also negative consequences, both for the individual and for the organization. Previous research has shown that the factors that represent potential causes and that can affect the level of job satisfaction are complex, different and come from different sources (Coomber \& Barriball 2007; Pan, 2015). In addition to the demographic or personal characteristics of employees, environmental factors or organizational factors that shape the work environment can be the cause of changes in the level of job satisfaction (Zeffane, 1994; Reiner \& Zhao, 1999; Ellickson \& Logsdon, 2001; Ellickson, 2002; Crossman \& Harris, 2006). Although there are a number of these factors, one of the most important factors whose modification can change the existing level of job satisfaction is HRM or the design of HRM activities.

Human resource management activities. The observed activities relate to policies, practices and systems that affect employee behaviour, attitudes and performance, and their main purpose is to ensure success through people, or to increase organizational efficiency and the ability of the organization to achieve its goals through effective use of available resources (Armstrong, 2017). As there is still no single position on the activities that are part of this function, different classifications of observed activities can be found in the literature. Nevertheless, most of these definitions include recruitment, selection, training, development and rewarding activities in HRM activities. Recruitment is the process of identifying and attracting candidates to fill vacancies in the organization (Zolak Poljašević, 2021), or the process of attracting qualified candidates in such numbers that will allow the organization to choose the best (Bogićević Milikić, 2017). Another activity in the field of human resources is the selection which is related to the selection of candidates through consideration of applications, interviews, testing, evaluation, job offers, obtaining references and preparation of employment contracts (Armstrong, 2017), or the procedure by which the candidates who best meet the requirements of a particular job are selected (Bahtijarević-Šiber, 1999). These two related activities are of great importance for the organization, given that their outcome directly affects other HRM activities, as well as 
organizational performance (Delaney \& Huselid, 1996; Ahmad \& Schroeder, 2003; Katou \& Budhwar, 2006). Employee training refers to an HRM activity that involves changes in specific knowledge, skills, abilities, attitudes, or behaviour (Bogićević Milikić, 2017). It is defined as a planned effort of the organization to improve the process of acquiring knowledge, skills and abilities that are crucial for efficient work (Štangl Šušnjar \& Zimanji, 2005; Noe et al., 2018), or as a process allowing employees to acquire specific competencies or help in correcting shortcomings related to their performance (GómezMejía et al., 2016). On the other hand, development is a set of systematic, planned activities that an organization conducts in order to enable employees to acquire new skills necessary to meet current and future job requirements (Werner \& DeSimone, 2012), i.e. the organization's effort to enable employees to acquire skills that will be needed by the organization in the future (Zolak Poljašević, 2021). Employee rewarding is a central feature of HRM (Torrington et al., 2017) and includes a system related to the money, goods and services that employees receive from the employer in exchange for their work, as well as a system for evaluating their performance (Bogićević Milikić, 2017). The basis of the observed system consists of rewards (compensations or salaries) which include all types of salaries or rewards paid to employees (Dessler, 2007).

The relationship between human resource management activities and job satisfaction. The analysis of existing studies (Lam et al., 2001; Holman, 2002; Chen et al., 2003; Lam \& Zhang, 2003; Garrido et al., 2005; Kuratko et al., 2005; Saura et al., 2005; González \& Garazo, 2006; Fillion et al., 2007; Cummings et al., 2008; Cerit, 2009; Kaya et al., 2010; Leppel et al., 2012; Gaki et al., 2013; Limbu et al., 2014; Kim et al., 2014; Huang \& Gamble, 2015; Tabvuma et al., 2015; Tanwar \& Prasad, 2016; Božović et al., 2019) has shown that there is a relatively small number of studies that adequately shed light on the relationship between the observed variables. Although previous research has certain shortcomings, the results obtained by the authors in previous studies have shown that there is a significant relationship between HRM activities and job satisfaction. Thus, based on a review of the existing literature, and starting from the defined subject of research and the basic goal, the basic hypothesis in the paper is defined as:

$\mathrm{H}_{0}$ : Human resource management activities have a positive effect on job satisfaction.

In order to study the observed relationship in detail, four additional hypotheses were defined, within which the nature and intensity of the relationship between each individual HRM activity and job satisfaction are examined separately. The defined additional hypotheses are:

$\mathrm{H}_{1}$ : Recruitment and selection have a positive effect on job satisfaction.

$\mathrm{H}_{2}$ : Training has a positive effect on job satisfaction.

$\mathrm{H}_{3}$ : Development has a positive effect on job satisfaction.

$\mathrm{H}_{4}$ : Rewarding has a positive effect on job satisfaction. 
When analysing the relationship between identified HRM activities and job satisfaction, the characteristics of individual HRM activities and their relationship to job satisfaction will be observed.

\section{Research methodology}

In order to examine the impact of HRM activities on job satisfaction and to test the set hypothesis, an empirical research was conducted through which primary data were collected in various organizations from the Republic of Srpska. Given the defined research question, subject and objectives of the research, the choice was made in favour of quantitative methodology, where the survey method was chosen for conducting research due to the numerous advantages that are desirable for the research of identified variables.

A specially created survey questionnaire consisting of three parts was used to collect data. The first part of the questionnaire included questions about the demographic characteristics of the respondents (gender, age, education level, position, work experience, tenure in the current organization) and general questions about the characteristics of the organization in which the respondents are employed (size, ownership, sector). The second part of the questionnaire included 20 questions on the independent variable (HRM), while the third part of the questionnaire included one question on the dependent variable (JS). The created questionnaire was delivered by e-mail to all organizations from the sample, with a request to forward it to all employees in the organization. The respondents submitted the answers directly to the researchers.

HRM activities as an independent variable was analysed through the satisfaction of respondents with different characteristics of HRM activities. The independent variable was assessed using 20 defined items or questions on HRM activities: recruitment and selection (three items), training (three items), development (four items) and rewarding (10 items). For the evaluation of job satisfaction (JS) as a dependent variable, a global score was used (Snipes et al., 2004) which provides a general assessment of the overall level of job satisfaction (Scarpello \& Campbell, 1983; Fields, 2002). Thus, job satisfaction was measured by one item or one question ("Overall, how satisfied are you with your job?"). Respondents expressed their satisfaction with all identified items using a five-point Likerttype scale (Likert, 1932), with responses ranging from "not at all satisfied" to "completely satisfied."

To justify the use of the created scale, the reliability of the scale was calculated based on the Cronbach's alpha coefficient (Cronbach, 1951), whose calculated value ( $\alpha=$ 0.911 ) shows that the proposed instrument is a reliable scale for assessing satisfaction with HRM activities.

In order to check and test the hypotheses that were defined on the basis of theoretical research, an empirical research was conducted and primary data were collected in various organizations from the Republic of Srpska. Based on the Business Register, which is a publicly available, unique database of business entities from the Republic of Srpska, a sample of organizations has been defined. From a set of 1,073 organizations, with a 
confidence level of $95 \%$ and a marginal error of 5\%, a simple, random sample of 283 organizations was formed, with the planned sample of respondents representing a set of all workers employed in selected organizations (6983 workers). By eliminating inadequately filled questionnaires and questionnaires with missing data, the final sample of 738 respondents was defined. The survey response rate of $10.57 \%$ represents an acceptable response rate when it comes to organizational surveys (Baruch \& Holtom, 2008).

The structure of the sample based on the demographic characteristics of the respondents and the characteristics of the organizations in which the respondents are employed is presented in Table 1 .

Table 1: Sample characteristics

\begin{tabular}{|c|c|c|c|}
\hline Variable & Labels & $\mathbf{n}$ & $\%$ \\
\hline Gender & $\begin{array}{l}\text { Male } \\
\text { Female }\end{array}$ & $\begin{array}{l}247 \\
491\end{array}$ & $\begin{array}{l}33.47 \\
66.53\end{array}$ \\
\hline Age & $\begin{array}{c}\text { Up to } 25 \text { years } \\
26-35 \text { years } \\
36-45 \text { years } \\
46-55 \text { years } \\
\text { More than } 56 \text { years }\end{array}$ & $\begin{array}{c}41 \\
252 \\
155 \\
141 \\
149 \\
\end{array}$ & $\begin{array}{c}5.55 \\
34.15 \\
21.00 \\
19.11 \\
20.19 \\
\end{array}$ \\
\hline Education level & $\begin{array}{l}\text { Primary school } \\
\text { Secondary school } \\
\text { High school } \\
\text { University degree } \\
\text { Master degree } \\
\text { PhD }\end{array}$ & $\begin{array}{c}11 \\
195 \\
65 \\
372 \\
77 \\
18\end{array}$ & $\begin{array}{c}1.49 \\
26.42 \\
8.81 \\
50.41 \\
10.43 \\
2.44 \\
\end{array}$ \\
\hline Position & $\begin{array}{c}\text { Managerial } \\
\text { Non-managerial }\end{array}$ & $\begin{array}{l}157 \\
581\end{array}$ & $\begin{array}{l}21.27 \\
78.73\end{array}$ \\
\hline Work experience & $\begin{array}{c}\text { Up to } 5 \text { years } \\
6-15 \text { years } \\
16-25 \text { years } \\
26-35 \text { years } \\
\text { More than } 35 \text { years }\end{array}$ & $\begin{array}{c}184 \\
218 \\
143 \\
147 \\
46 \\
\end{array}$ & $\begin{array}{c}24.93 \\
29.54 \\
19.38 \\
19.92 \\
6.23 \\
\end{array}$ \\
\hline $\begin{array}{c}\text { Tenure in the current } \\
\text { organisation }\end{array}$ & $\begin{array}{c}\text { Up to } 5 \text { years } \\
6-15 \text { years } \\
16-25 \text { years } \\
\text { 26-35 years } \\
\text { More than } 35 \text { years }\end{array}$ & $\begin{array}{c}306 \\
209 \\
130 \\
81 \\
12\end{array}$ & $\begin{array}{c}41.46 \\
28.32 \\
17.62 \\
10.97 \\
1.63\end{array}$ \\
\hline Size & $\begin{array}{c}\text { Small (up to } 50 \text { employees) } \\
\text { Medium (51-100 employees) } \\
\text { Large (more than } 100 \text { employees) }\end{array}$ & $\begin{array}{l}180 \\
383 \\
175\end{array}$ & $\begin{array}{l}24.39 \\
51.90 \\
23.71\end{array}$ \\
\hline Ownership & $\begin{array}{l}\text { State-owned } \\
\text { Private }\end{array}$ & $\begin{array}{l}315 \\
423\end{array}$ & $\begin{array}{l}42.68 \\
57.32\end{array}$ \\
\hline Sector & $\begin{array}{l}\text { Manufacture } \\
\text { Services }\end{array}$ & $\begin{array}{l}224 \\
514\end{array}$ & $\begin{array}{l}30.35 \\
69.65 \\
\end{array}$ \\
\hline
\end{tabular}

Source: Authors research 


\section{Research results}

Based on the data on descriptive measures (arithmetic mean and standard deviation) for the dependent and independent variables, which are presented in Table 2, it can be seen that the respondents from the sample are satisfied with the HRM activities $(M=3.2849)$, as well as with all identified HRM activities (the estimated level of satisfaction for each variable has a value above the neutral mean). If, based on the results of the research, the observed variables are ranked according to the assessed level of satisfaction, it can be noticed that the respondents from the sample are on average most satisfied with RS $(M=3.5136)$, then with $\mathrm{T}(\mathrm{M}=3.3166)$, then with $\mathrm{D}(\mathrm{M}=3.2930)$, while the average level of satisfaction of the respondents is the lowest with $\mathrm{R}(\mathrm{M}=3,204)$. The data from the table show that the answers of the respondents deviated the most from the arithmetic mean in $\mathrm{T}$ ( $\mathrm{SD}=$ 1.06866), while the average smallest deviation occurred in $\mathrm{RS}(\mathrm{SD}=1.00783)$.

Table 2: Descriptive Statistics (Times New Roman 8pt Italic)

\begin{tabular}{|c|c|c|c|}
\hline & N & Mean & Std. Deviation \\
\hline RS & 738 & 3.5136 & 1.00783 \\
T & 738 & 3.3166 & 1.06866 \\
D & 738 & 3.2930 & 1.06517 \\
R & 738 & 3.204 & 1.0382 \\
HRM & 738 & 3.2849 & .97799 \\
Valid N (listwise) & 738 & & \\
\hline
\end{tabular}

Source: SPSS

Based on the results of the conducted empirical research, the defined hypotheses were tested. To test the hypothesis about the relationship between HRM activities and JS, as well as the hypothesis about the relationship between individual HRM activities (RS, T, $\mathrm{D}$ and R) and JS, correlation analysis was used. The summary results are shown in Table 3.

Table 3: Summary results of correlation analysis

\begin{tabular}{|c|c|c|c|c|c|c|c|}
\hline & & RS & $\mathbf{T}$ & D & $\mathbf{R}$ & HRM & $\mathbf{J S}$ \\
\hline \multirow{3}{*}{ RS } & Spearman's rho & 1.000 & $.756^{* *}$ & $.829^{* *}$ & $.748^{* *}$ & $.846^{* *}$ & $.736^{* *}$ \\
\hline & Sig. (2-tailed) & & .000 & .000 & .000 & .000 & .000 \\
\hline & $\mathrm{N}$ & 738 & 738 & 738 & 738 & 738 & 738 \\
\hline \multirow{3}{*}{$\mathbf{T}$} & Spearman's rho & $.756^{* *}$ & 1.000 & $.864^{* *}$ & $.835^{* *}$ & $.904^{* *}$ & $.821^{* *}$ \\
\hline & Sig. (2-tailed) & .000 & & .000 & .000 & .000 & .000 \\
\hline & $\mathrm{N}$ & 738 & 738 & 738 & 738 & 738 & 738 \\
\hline \multirow{3}{*}{ D } & Spearman's rho & $.829^{* *}$ & $.864^{* *}$ & 1.000 & $.872^{* *}$ & $.941^{* *}$ & $.849^{* *}$ \\
\hline & Sig. (2-tailed) & .000 & .000 & & .000 & .000 & .000 \\
\hline & $\mathrm{N}$ & 738 & 738 & 738 & 738 & 738 & 738 \\
\hline \multirow{3}{*}{$\mathbf{R}$} & Spearman's rho & $.748^{* *}$ & $.835^{* *}$ & $.872^{* *}$ & 1.000 & $.970^{* *}$ & $.887^{* *}$ \\
\hline & Sig. (2-tailed) & .000 & .000 & .000 & & .000 & .000 \\
\hline & $\mathrm{N}$ & 738 & 738 & 738 & 738 & 738 & 738 \\
\hline HRM & Spearman's rho & $.846^{* *}$ & $.904^{* *}$ & $.941^{* *}$ & $.970^{* *}$ & 1.000 & $.891^{* *}$ \\
\hline
\end{tabular}




\begin{tabular}{|c|l|r|r|r|r|r|r|}
\hline \multirow{2}{*}{ JS } & Sig. (2-tailed) & .000 & .000 & .000 & .000 & & .000 \\
\cline { 2 - 8 } & $\mathrm{N}$ & 738 & 738 & 738 & 738 & 738 & 738 \\
\hline \multirow{3}{*}{ SS } & Spearman's rho & $.736^{* *}$ & $.821^{* *}$ & $.849^{* *}$ & $.887^{* *}$ & $.891^{* *}$ & 1.000 \\
\cline { 2 - 8 } & Sig. (2-tailed) & .000 & .000 & .000 & .000 & .000 &. \\
\cline { 2 - 8 } & $\mathrm{N}$ & 738 & 738 & 738 & 738 & 738 & 738 \\
\hline \multirow{2}{*}{ **. Correlation is significant at the 0.0 level (2-tailed). }
\end{tabular}

Source: SPSS

Based on the data from the previous table, the test results of the hypothesis, the calculated values of the correlation coefficient $\left(r_{s}=0.891\right)$ and the calculated $p$ values $(p=$ 0.000 ), it can be concluded that the correlation coefficient is positive and that there is a direct monotonic relationship in the sample. Also, the research results show that there is a strong correlation in the sample, and that for any level of significance it can be concluded that there is a quantitative correlation of the observed variables, i.e. that the observed relationship between HRM activities and JS is statistically significant. As the respondents with a higher degree of satisfaction with HRM activities have a higher degree of overall job satisfaction (JS), the basic hypothesis, stating that "there is a strong positive relationship between human resource management activities (HRM) and job satisfaction (JS)", was proved

Based on the results of the research, the statistical significance of the relationship between individual HRM activities (RS, T, D and R) and JS can be analysed and other hypotheses can be tested. From the analysis of the results from the previous table, it can be seen that all observed relationships are statistically significant, with the strongest correlation between R and JS ( $\left.r_{s}=0.887 ; p=0.000\right)$, then between D and JS $\left(r_{s}=0.849 ; p\right.$ $=0.000)$, then between $\mathrm{T}$ and $\mathrm{JS}\left(\mathrm{r}_{\mathrm{s}}=0.821 ; \mathrm{p}=0.000\right)$, while the weakest correlation occurs between RS and JS $\left(r_{s}=0.736 ; p=0.000\right)$. Based on the calculated values, it can be noticed that there are strong correlations in the sample, as well as that for any level of significance it can be concluded that there is a quantitative correlation of the observed variables, or that the relationships between individual HRM activities (RS, T, D and R) and JS are statistically significant. As the respondents with a higher degree of satisfaction with individual HRM activities have a higher degree of overall job satisfaction (JS), it can be concluded that hypotheses $\mathrm{H} 1, \mathrm{H} 2, \mathrm{H} 3$ and $\mathrm{H} 4$ are correct.

\section{Discussion}

A review of the existing literature has shown that the relationship between HRM activities on the one hand, and job satisfaction on the other, can be found in the available literature and that there are also a number of studies examining the impact of HRM activities on job satisfaction. Thus, the results of the conducted research can be compared with the results of conceptually similar research. When it comes to the impact of HRM and its activities on job satisfaction, a review of the relevant literature did not find any research that studies the relationship between HRM activities and job satisfaction in organizations operating in neighbouring countries in a conceptually similar way. However, a review of all previous research can identify a number of studies that, among other things, analyse the existence and nature of the relationship between the observed activities and job satisfaction (Lam et 
al., 2001; Holman, 2002; Chen et al., 2003; Lam \& Zhang, 2003; Garrido et al., 2005; Kuratko et al., 2005; Saura et al., 2005; González \& Garazo, 2006; Fillion et al., 2007; Cummings et al., 2008; Cerit, 2009; Kaya et al., 2010; Leppel et al., 2012; Gaki et al., 2013; Limbu et al., 2014; Kim et al., 2014; Huang \& Gamble, 2015; Tabvuma et al., 2015; Tanwar \& Prasad, 2016; Božović et al., 2019).

A more detailed analysis of the theoretical, methodological and conceptual aspects of the analysed research shows that the observed HRM activities in the analysed research were identified as independent variables. However, if the conceptual framework is taken into account, previous research can be classified into two groups. The first group includes research in which these activities are viewed as one of the factors that can affect the level of job satisfaction, while the second group includes research in which certain activities are viewed through the analysis of human resources practices, or as activities in the field of HRM. Of the observed activities, the activity of rewarding was most often studied, followed by training and development of employees, while the activities of recruitment and selection were less often the subject of study.

When it comes to research methodology, the authors of most studies opted for a quantitative methodology, where the collection of primary data was done using a questionnaire. The respondents in the research were workers who are employed in organizations that operate in various fields. In most of these studies, the authors came to the results that show that there is a statistically significant impact of the observed HRM activities on job satisfaction, which is confirmed by the results of research conducted in this paper, while the results of two studies prove otherwise (Cummings et al., 2008; Limbu et al., 2014).

Although there are many studies in which authors have analysed the impact of HRM activities on job satisfaction in different ways, previous research lacks comprehensiveness. Due to the inclusion of only certain activities in the analysis, there is a need for additional research on the impact of HRM activities on job satisfaction, which will include a comprehensive analysis of all these activities.

\section{Conclusion}

The main purpose of this paper was to examine the nature and strength of the relationship between HRM activities and job satisfaction, by examining the impact of individual HRM activities on job satisfaction. Four HRM activities were included in the analysis, namely: recruitment and selection, training, development and rewarding of employees. The choice of these activities is justified on the basis of a review of the literature which shows that HRM activities most often include these activities. In order to confirm the defined hypotheses and to investigate the relationship between the defined variables, an empirical research was conducted using a specially created survey questionnaire. The research included a sample of 738 respondents who were employed in various organizations from the Republic of Srpska. The results of the research confirmed the results of previous research and proved that there is a statistically significant positive relationship between HRM activities and job satisfaction. 
Although a review of the available literature reveals a number of studies that have studied the relationship between HRM activities and job satisfaction, this research has certainly made some scientific contribution. Unlike previous studies that had a partial approach, the conducted study studied the impact of HRM activities on job satisfaction comprehensively, taking into account a number of characteristics that have not been studied in previous research; thus, this article expanded the existing fund of knowledge about the relationship between HRM activities and job satisfaction. Also, the contribution of the paper is the fact that the relationship between HRM activities and job satisfaction was confirmed on a sample that includes a large number of workers employed in many different organizations, unlike previous surveys that were conducted on samples of respondents coming from one organization or from several organizations performing the same activity. The scientific contribution is reflected in the created scale for assessing the satisfaction of HRM activities, which can be used to assess the satisfaction of employees with HRM, as well as with existing HRM activities. As the results of the conducted research confirmed the existence and explained the nature of the relationship between the observed variables, a certain contribution to practice was realized. Managers of various organizations from the Republic of Srpska and the surrounding countries were given a tool with which they can measure employee satisfaction with different characteristics of human resource management. By changing the characteristics that have the greatest impact on the level of job satisfaction, managers have the opportunity to influence the existing level of employee satisfaction. In this way, the negative effects that occur as a result of employee dissatisfaction can be reduced and all the positive consequences provided by the increase in job satisfaction can be used.

The conducted research also has certain limitations. The first limitation concerns the way in which the defined variables were evaluated. By studying HRM activities through the satisfaction of respondents with the identified characteristics of HRM activities, it is not possible to collect and analyse data on existing HRM activities in organizations. It is recommended that in future surveys, the evaluation of variables is performed in such a way that, in addition to data on satisfaction, data on the existing characteristics of HRM activities are also collected. Another limitation is the choice of survey method that does not allow for deeper analysis of HRM activities at the level of individual organizations, so in future research it would be desirable to use other methods that would allow for deeper analysis of HRM activities. The third limitation refers to the way the research is conducted, due to which there is a possibility that the questionnaire was not forwarded to all potential respondents. It is recommended to send questionnaires directly to the addresses of the respondents. The fourth limitation refers to the problem of generalization of the obtained results, considering that the sample in the research included employed workers from the Republic of Srpska. It is recommended to conduct additional research using the created questionnaire, which would include workers employed in countries in the region and in various organizations around the world. 


\section{References}

Ahmad, S., \& Schroeder, R.G. (2003). The impact of human management practices on operational performance: recognizing country and industry differences. Journal of Operations Management, 21(1), 19-43. Doi: https://doi.org/10.1016/S0272-6963(02)00056$\underline{6}$

Aleksić-Glišović, M., Jerotijević, G., \& Jerotijević, Z. (2019). Modern approaches to employee motivation. Ekonomika, 65(2), 121-133. Doi: https://doi.org/10.5937/ekonomika1902121A

Armstrong, M. (2017). Armstrong's Handbook of Human Resource Management Practice. London: Kogan Page.

Bahtijarević-Šiber, F. (1999). Menadžment ljudskih potencijala. Zagreb: Golden marketing. Barney, J. B. (1991). Firm resources and sustained competitive advantage. Journal of Management, 17(1), 99-120. Doi: https://doi.org/10.1177/014920639101700108

Barney, J. B., \& Wright, P. M. (1998). On becoming a strategic partner: the role of human resource in gaining competitive advantage. Human Resource Management, 37(1), 31-46. Doi: https://doi.org/10.1002/(SICI)1099-050X(199821)37:1<31::AID-HRM4>3.0.CO;2-W

Baruch, Y., \& Holtom, B. C. (2008). Survey response rate levels and trends in organizational research. Human Relations, 61(8), 1139-1160. Doi: https://doi.org/10.1177/0018726708094863

Bogićević Milikić, B. (2017). Menadžment ljudskih resursa. Beograd: Ekonomski fakultet.

Božović, J., Božović, I., \& Ljumović, I. (2019). Impact of HRM practices on job satisfaction of employees in Serbian banking sector. Management: Journal of Sustainable Business and Management Solutions in Emerging Economies, 24(1), 63-76.

Cerit, Y. (2009). The effects of servant leader ship behaviours of school principals on teachers' job satisfaction. Educational Management Administration \& Leadership, 37(5), 600-623. Doi: https://doi.org/10.1177/1741143209339650

Chen, T. Y., Chang, P. L., \& Yeh, C. W. (2003). The study of career needs, career development programmes and job satisfaction levels of R\&D personnel: the case of Taiwan. International Journal of Human Resource Management, 14(6), 1001-1026. Doi: https://doi.org/10.1080/0958519032000106182

Coomber, B., \& Barriball, K. L. (2007). Impact of job satisfaction components on intent to leave and turnover for hospital-based nurses: a review of the research literature. International Journal of Nursing Studies, 44(2), 297-314. Doi: https://doi.org/10.1016/j.ijnurstu.2006.02.004

Cronbach, L. J. (1951). Coefficient alpha and the internal consistency of tests. Psychometrika, 16(3), 297-334. 
Crossman, A., \& Harris, P. (2006). Job satisfaction of secondary school teachers. Educational Management Administration and Leadership, 34(1), 29-46. Doi: https://doi.org/10.1177/1741143206059538

Cummings, G. G., Olson, K., Hayduk, L., Bakker, D., Fitch, M., Green, E., Butler, L., \& Conlon, M. (2008). The relationship between nursing leadership and nurses' job satisfaction in Canadian oncology work environments. Journal of Nursing Management, 16(5), 508518. Doi: https://doi.org/10.1111/j.1365-2834.2008.00897.x

Currall, S. C., Towler, A. J., Judge, T. A., \& Kohn, L. (2005). Pay satisfaction and organizational outcomes. Personnel Psychology, 58(3), 613-640. Doi: https://doi.org/10.1111/j.1744-6570.2005.00245.x

Davis, G. (2004). Job satisfaction survey among employees in small business. Journal of Small Business and Enterprise Development, 11(4), 491-503. Doi: https://doi.org/10.1108/14626000410567143

Delaney, J. T., \& Huselid, M. A. (1996). The impact of human resource management practices on perceptions of organizational performance. Academy of Management Journal, 39(4), 949-969. Doi: https://doi.org/10.5465/256718

Dessler, G. (2007). Osnovi menadžmenta ljudskih resursa. Beograd: Data status.

Ellickson, M. C. (2002). Determinants of job satisfaction of municipal government employees. Public Personnel Management, 31(3), 343-358. Doi: https://doi.org/10.1177/009102600203100307

Ellickson, M. C., \& Logsdon, K. (2001). Determinants of job satisfaction of municipal government employees. State Local Government Review, 33(3), 173-184. Doi: https://doi.org/10.1177/0160323X0103300302

Fields, D. L. (2002). Taking the measure of work: A guide to validated scales for organizational research and diagnosis. Thousand Oaks: Sage Publications.

Fillion, L., Tremblay, I., Truchon, M., Côté, D., Struthers, C. W., \& Dupuis, R. (2007). Job satisfaction and emotional distress among nurses providing palliative care: empirical evidence for an integrative occupational stress-model. International Journal of Stress Management, 14(1), 1-25.

Gaki, E., Kontodimopoulos, N., \& Niakas, D. (2013). Investigating demographic, workrelated and job satisfaction variables as predictors of motivation in Greek nurses. Journal of Nursing Management, 21(3), 483-490. Doi: https://doi.org/10.1111/j.1365$\underline{2834.2012 .01413 . x}$

Garrido, M. J., Pérez, P., \& Antón, C. (2005). Determinants of sales manager job satisfaction. An analysis of Spanish industrial firms. International Journal of Human Resource Management, 16(10), 1934-1954. Doi: https://doi.org/10.1080/09585190500298776 
George, J., \& Jones, G. (2012). Understanding and managing organizational behaviour. Upper Saddle River: Prentice Hall.

Gómez-Mejía, L. R., Balkin, D. B., \& Cardy, R. L. (2016). Managing human resources. Boston: Pearson Education.

González, J. V., \& Garazo, T. G. (2006). Structural relationships between organizational service orientation, contact employee job satisfaction and citizenship behaviour. International Journal of Service Industry Management, 17(1), 23-50. Doi: https://doi.org/10.1108/09564230610651561

Heneman, R. (2007). Implementing Total Rewards Strategies: A guide to successfully planning and implementing a total rewards system. USA: Society for Human Resource Management Foundation.

Holman, D. (2002). Employee wellbeing in call centres. Human Resource Management Journal, 12(4), 35-50.

Huang, Q., \& Gamble, J. (2015). Social expectations, gender and job satisfaction: Frontline employees in China's retail sector. Human Resource Management Journal, 25(3), 331347. Doi: https://doi.org/10.1111/1748-8583.12066

Huselid, M. A. (1995). The impact of human resource management practices on turnover, productivity, and corporate financial performance. Academy of Management Journal, 38(3), 635-672. Doi: https://doi.org/10.5465/256741

Katou, A. A., \& Budhwar, P. S. (2006). Human resource management systems and organizational performance: a test of a mediating model in the Greek manufacturing context. International Journal of Human Resource Management, 17(7), 1223-1253. Doi: https://doi.org/10.1080/09585190600756525

Kaya, N., Koc, E., \& Topcu, D. (2010). An exploratory analysis of the influence of human resource management activities and organizational climate on job satisfaction in Turkish banks. International Journal of Human Resource Management, 21(10), 2031-2051. Doi: https://doi.org/10.1080/09585192.2010.505104

Kim, J., Wehbi, N., DelliFraine, J. L., \& Brannon, D. (2014). The joint relationship between organizational design factors and HR practice factors on direct care workers' job satisfaction and turnover intent. Health Care Management Review, 39(2), 174-184. Doi: https://doi.org/10.1097/HMR.0b013e31828c8b8f

Kuratko, D. F., Hornsby, J. S., \& Bishop, J. W. (2005). Managers' corporate entrepreneurial actions and job satisfaction. International Entrepreneurship and Management Journal, 1(3), 275-291.

Lam, T., Baum, T., \& Pine, R. (2001). Study of managerial job satisfaction in Hong Kong's Chinese restaurants. International Journal of Contemporary Hospitality Management, 13(1), 35-42. Doi: https://doi.org/10.1108/09596110110365634 
Lam, T., \& Zhang, H. Q. (2003). Job satisfaction and organizational commitment in the Hong Kong fast food industry. International Journal of Contemporary Hospitality Management, 15(4), 214-220. Doi: https://doi.org/10.1108/09596110310475667

Leppel, K., Brucker, E., \& Cochran, J. (2012). The importance of job training to job satisfaction of older workers. Journal of Aging \& Social Policy, 24(1), 62-76. Doi: https://doi.org/10.1080/08959420.2012.629136

Likert, R. (1932). A technique for the measurement of attitudes. Archives of Psychology, 22(140), 5-53.

Limbu, Y. B., Jayachandran, C., \& Babin, B. J. (2014). Does information and communication technology improve job satisfaction? The moderating role of sales technology orientation. Industrial Marketing Management, 43(7), 1236-1245. Doi: https://doi.org/10.1016/j.indmarman.2014.06.013

Locke, E. A. (1969). What is job satisfaction?. Organizational Behaviour and Human Performance, 4(4), 309-336. Doi: https://doi.org/10.1016/0030-5073(69)90013-0

Locke, E. A. (1976). The Nature and Causes of Job Satisfaction. In: Dunnnette, M. D. (ed.), Handbook of Industrial and Organizational Psychology. Chicago: Rand McNally, pp. 1297-1343.

Mathis, R. L., Jackson, J., \& Valentine, S. (2015). Human Resource Management: Essential Perspectives. Boston: Cengage Learning.

McPhail, R., Patiar, A., Herington, C., Creed, P., \& Davidson, M. (2015). Development and initial validation of a hospitality employees' job satisfaction index: evidence from Australia. International Journal of Contemporary Hospitality Management, 27(8), 18141838. Doi: https://doi.org/10.1108/IJCHM-03-2014-0132

Noe, R. A., Hollenbeck, J. R., Gerhart, B., \& Wright, P. M. (2018). Fundamentals of Human Resource Management. New York: McGraw-Hill/Irwin.

Paauwe, J. (2004). HRM and Performance: Achieving Long-Term Viability. Oxford: Oxford University Press.

Pan, F. C. (2015). Practical application of importance-performance analysis in determining critical job satisfaction factors of a tourist hotel. Tourism Management, 46, 84-91. Doi: https://doi.org/10.1016/j.tourman.2014.06.004

Purcell, J., Kinnie, K., Hutchinson, S., Rayton, B., \& Swart, J. (2003). People and Performance: How People Management Impacts on Organisational Performance. London: CIPD.

Reiner, M. D., \& Zhao, J. (1999). The determinants of job satisfaction among United States air force security police: a test of rival theoretical predictive models. Review of Public Personnel Administration, 19(5), 5-18. Doi: https://doi.org/10.1177/0734371X9901900301 
Saura, I. G., Contrí, G. B., Taulet, A. C., \& Velázquez, B. M. (2005). Relationships among customer orientation, service orientation and job satisfaction in financial services. Journal of Service Management, 16(5), 497-525. Doi: https://doi.org/10.1108/09564230510625787

Scarpello, V., \& Campbell, J. P. (1983). Job satisfaction: Are all the parts there? Personnel Psychology, 36(3), 577-600. Doi: https://doi.org/10.1111/j.1744-6570.1983.tb02236.x

Snipes, R. L., Oswald, S. L., LaTour, M., \& Armenakis, A. A. (2004). The effects of specific job satisfaction facets on customer perceptions of service quality: an employeelevel analysis. Journal of Business Research, 58(10), 1330-1339. Doi: https://doi.org/10.1016/j.jbusres.2004.03.007

Štangl Šušnjar, G., \& Zimanji, V. (2005). Menadžment ljudskih resursa. Subotica: Ekonomski fakultet.

Tabvuma, V., Georgellis, Y., \& Lange, T. (2015). Orientation training and job satisfaction: a sector and gender analysis. Human Resource Management, 54(2), 303-321. Doi: https://doi.org/10.1002/hrm.21650

Tanwar, K., \& Prasad, A. (2016). The effect of employer brand dimensions on job Satisfaction: gender as a moderator, Management Decision, 54(4), 854-886. Doi: https://doi.org/10.1108/MD-08-2015-0343

Torrington, D., Hall, L., Atkinson, C., \& Taylor, S. (2017). Human Resource Management. Harlow: Pearson Education.

Tyson, S. (2015). Essentials of Human Resource Management. New York: Routledge.

Vemić-Đurković, J., Nikolić, I., \& Marinović-Matović, I. (2020). Human resource management in the function of improving the quality of banks' business as a support in financing agriculture in Serbia. Ekonomika poljoprivrede, 67(3), 781-796.

Wang, H. C., \& Barney, J. B. (2006). Employee incentives to make firm-specific investments: implications for resource-based theories of corporate diversification. Academy of Management Review, 31(2), 466-476. Doi: https://doi.org/10.5465/amr.2006.20208691

Werner, J. M., \& DeSimone, R. L. (2012). Human Resource Development. Mason: Thomson South-Western.

Zeffane, R. M. (1994). Correlates of job satisfaction and their implications for work redesign: a focus on the Australian telecommunications industry. Public Personnel Management, 23(1), 62-76. Doi: https://doi.org/10.1177/009102609402300105

Zolak Poljašević, B. (2021). Menadžment ljudskih resursa. Banja Luka: Ekonomski fakultet Univerziteta u Banjoj Luci. 
